\title{
PERILAKU KONSUMEN TERHADAP KEPUTUSAN PEMBELIAN BERAS MERAH DI PASAR TEMBOK SURABAYA
}

\author{
Ramon Syahrial $^{1)}$, Oscarius Yudhi Ari Wijaya ${ }^{2)^{*}}$ \\ ${ }^{1}$ Jurusan Agribisnis Fakultas Pertanian, Universitas Wijaya Putra \\ E-mail: ramonsyahrial@uwp.ac.id \\ ${ }^{2}$ Program Studi Administrasi Perkantoran, Akademi Sekretari dan Manajemen Indonesia \\ (ASMI) Surabaya \\ *Corresponding E-mail: artaprima@gmail.com
}

\begin{abstract}
The method uses analysis in the form of test equivalence, reliability test, multiple linear regression, coefficient of determination and hypothesis testing with the f test and the T test with the help of the program (SPSS) 16.0. Based on the results of the analysis, the regression equation $Y=0.150+0.365 X 1+0.370 X 2+0.390 X 3+$ $0.433 X 4+e$ constant is 0.150 . meaning that if the free value is 0 , then the $Y$ value is 0.150 with the coefficient of cultural variables (X1) of 0.365, social (X2) of 0.370, personal (X3) of 0.390 and psychological (X4) of 0.433 which means that it is positive. From the results of the thypothesis test, it was obtained that the tcount of cultural variables was 2.562, social variables were 1.911, personal variables were 1.715, and psychological variables were 1.542. Only cultural variables have an effect with a value of 2.562 so that the tcount> is compared with the ttable value of 2.05954. Based on the simultaneous F test, the value of Fcount is 5,628> F table 2,7822 and the significance is $0,000<0,05$. The results of the $R$ correlation test show that the $R$ value is 0.455 , so the $R$ correlation between $X$ and $Y$ variables has a less strong relationship. The $R 2$ value of $19.8 \%$ means that $19.8 \%$ of purchasing decisions are influenced by culture, social, personal and psychological. While the consumer's biggest decision in purchasing brown rice at the Surabaya Wall market is influenced by other variables, the remaining $80.2 \%$ is influenced by other variables outside of this study.
\end{abstract}

Keywords: purchasing decisions, cultural, social, personal, psychological

\section{PENDAHULUAN}

Beras merah mempunya ciri-ciri serta manfaat yang berbeda dengan jenis beras yang dikonsumsi pada umumnya. Beras merah organik diperlukan tindakan perawatan yang jauh berbeda dengan produk beras-beras pada umumnya. (Andriana, 2006)

Dengan kelebihan ataupun manfaat beras merah, banyak orang yang mengkonsumsi beras merah, karena memiliki manfaat yang cukup membuat banyak orang tertarik.

Harga beras merah lebih tinggi di pasaran dari pada beras biasa dikarenakan kualitas kandungan (Sutisna, 2013)dan pengolahan pasca panennya yang mempunyai nilai lebih. Dalam tampilan kemasan, beras merah banyak dikemas secara eksklusif untuk konsumennya. (Suryani, 2013)

Konsumsi beras merah belum begitu banyak dibandingkan dengan beras putih dan sampai saat ini masih didominasi oleh kalangan dewasa, karena mereka peduli dengan kesehatannya.(Sangadji, 2017); (Setiadi, 2010) Sedangkan trend untuk kalangan muda yang mengkonsumsi beras merah biasanya bertujuan untuk menurunkan berat badan.(Istijanto, 2013) 
Disamping hal tersebut diatas agar konsumen merasa puas dengan suatu produk atau jasa yang dijual (Kotler \& Amstrong, 2004)(Setiadi, 2015), diperlukan langkah-langkah yang efektif, salah satunya adalah memahami dan mengetahui perilaku konsumen yang diukur melalui aktivitas, minat dan pendapat dari konsumen . (Utami, 2008) Memahami perilaku konsumen bukan merupakan masalah sederhana, karena mereka lebih menanggapi pengaruh yang mengubah pikiran terakhir.

Keputusan pembelian terhadap suatu produk sangat dipengaruhi oleh perilaku konsumen. (Fitriani, 2006) Keputusan pembelian adalah tindakan konsumen dalam memenuhi keinginan (Armstrong et al., 2014) dan kebutuhan yang merupakan proses penentuan sikap atau pembelian terhadap barang dan jasa, untuk memahami perilaku konsumen dalam pembelian membutuhkan proses dikarenakan setiap saat manusia mengalami perubahan.(Santika, A., 2010)(Supranto \& Limakrisna, 2007)

Tujuan Penelitian melakukan analisa mengenai: 1. Proses pengambilan keputusan konsumen dalam pembelian beras merah di pasar Tembok Surabaya. 2. Komponen-komponen dominan yang mempengaruhi konsumen dalam membeli beras merah di pasar Tembok Surabaya.

\section{Hipotesis}

Berdasarkan latar belakang masalah dan tinjauan pustaka yang telah diuraikan di atas, makadapat diajukan hipotesis sebagai berikut:

H1 : Diduga faktor budaya berpengaruh positif terhadap keputusan pembelian

$\mathrm{H} 2$ : Diduga faktor sosial berpengaruh positif terhadap keputusan pembelian

H3 : Diduga faktor pribadi berpengaruh positif terhadap keputusan pembelian

H4 : Diduga faktor psikologis berpengaruh positif terhadap keputusan pembelian

H5 : Diduga faktor sosial paling berpengaruh dalam pengambilan keputusan pembelian

\section{METODE PENELITIAN}

\section{Analisis Data}

(Azwar, 2012) Guna menentukan batas-batas kebenaran dan ketepatan alat ukur (Kuesioner) suatu indikator variabel penelitian dapat dilakukan dengan cara sebagai berikut:

Validitas

Uji validitas data yang digunakan untuk mengukur sah atau valid tidaknya suatu kuesioner, biasanya dilakukan uji signifikan koefisien korelasi pada taraf signifikan 0,05. Menurut Azwar dalam buku (Duwi, 2010) digunakan untuk mengukur valid tidaknya suatu kuesioner. Dalam menentukan valid atau tidaknya suatu item pengujian sering digunakan korelasi Corrected ItemTotal Correlation. Suatu item dikatakan valid apabila nilai CorrectedItem- Total Correlation > dibandingkan 0,3. Item kuesioner yang valid dapat dijadikan acuan untuk penelitian selanjutnya

Uji Reliabilitas

Pengujian Reliabilitas dilakukan untuk mengetahui seberapa besar tingkat keabsahan data sehingga dapat menghasilkan data yang benar-benar sesuai dengan kenyataan dan dapat digunakan berkali-kali pada waktu yang berbeda, pengujian ini menggunakan uji Crobach alpha $(\propto)$ yaitu jika $\propto>0,60$ maka dikatakan reliabel (Ghozali, 2006)

Uji Regresi Linear Berganda

Regresi linear berganda digunakan untuk menghitung dan atau menguji tingkat signifikan (Hartono, 2004). Analisis regresi berganda merupakan teknik analisis yang umum digunakan dalam menganalisis hubungan dan pengaruh satu variabel terikat $(\mathrm{Y})$ dengan dua atau lebih variabel bebas (X). Metode Regresi Linear berganda dapat dihitung dengan menggunakan rumus:

$$
\mathrm{Y}=\mathrm{a}+\mathrm{b} 1 \mathrm{X} 1+\mathrm{b} 2 \mathrm{X} 2+\mathrm{b} 3 \mathrm{X} 3+\mathrm{b} 4 \mathrm{X} 4+\mathrm{e}
$$




$\begin{array}{ll}\text { Dimana: } & \text { Y }=\quad \text { Keputusan pembelian } \\ \mathrm{A}= & \text { Konstanta } \\ \mathrm{X} 1= & \text { Budaya } \\ \mathrm{X} 2= & \text { Sosial } \\ \mathrm{X} 3= & \text { Pribadi } \\ \mathrm{X} 4= & \text { Psikologis } \\ \mathrm{b} 1= & \text { Koefisien regresi variabel budaya } \\ \mathrm{b} 2= & \text { Koefisien regresi variabel sosial } \\ \mathrm{b} 3= & \text { Koefisien regresi variabel pribadi } \\ \mathrm{b} 4= & \text { Koefisien regresi variabel psikologis } \\ \mathrm{e}= & \text { Error }\end{array}$

Uji Determinasi (R2)

Analisis determinasi digunakan untuk mengetahui persentase sumbangan variabel independen (X1,X2,X3,X4) secara serentak terhadap variabel dependen (Y) (Duwi, 2010). Jika nilai R2 sama dengan1, maka persentase sumbangan pengaruh yang diberikan variabel independen terhadap variabel dependen adalah sempurna atau baik. Koefisien korelasi (R) adalah uji yang digunakanuntukmengetahuiadanyahubunganyang kuatataupunrendahantara kedua varibel berdasarkan nilai $\mathrm{R}$ menurut (Sugiyono, 2007) pedoman untuk memberikan interprestasi koefisien korelasi.

\section{Uji Hipotesis}

Uji Anova F (Secara simultan)

UjiF dilakukan untuk memperhatikan apakah seluruh variabel bebas mempengaruhi variabelterikat. Untuk membuktikan kebenaran hipotesis digunakan uji F secara Stimultan yaitu dengan membandingkan $\mathrm{F}_{\text {hitung dengan }} \mathrm{F}$ tabel, dimana: $\mathrm{F}$ hitung $>\mathrm{F}$ tabel pada tingkat signifikan $=$ 0.05 Apabila $F_{\text {hitung }}$ lebih besar dari pada $F_{\text {tabel }}\left(F_{\text {hitung }}>F_{\text {tabel }}\right)$ yang berarti variabel bebas secara bersama-sama berpengaruh terhadap terikat maka (Ho ditolak, Ha diterima). Apabila $F_{\text {hitung lebih }}$ kecil dari pada $F_{\text {tabel }}\left(F_{\text {hitung }}<F_{\text {tabel }}\right)$ berarti variabel bebas tidak berpengaruh signifikan terhadap variabel terikat. (Ho diterima Ha ditolak).

Uji Parsial (Uji T)

Untuk menentukan koefisien spesifik yang mana yang tidak sama dengan nol, uji tambahan diperlukan yaitu dengan menggunakan uji t. Uji statistik t pada dasarnya menunjukkan seberapa jauh pengaruh satu variabel independen secara individual dalam menerangkan variasi variabel dependen (Imam, 2005). Signifikansi koefisien parsial ini memiliki distribusi t dengan derajat kebebasan $n-k-1$, dan signifikan pada $\alpha=0,05$. Dengan kriteria pengambilan keputusan sebagai berikut:

1. Bila $t_{\text {hitung }}>t_{\text {tabel }}$ maka Ho ditolak dan hipotesis alternatif (Ha) diterima.

2. Bila $t_{\text {hitung }}<t_{\text {tabel }}$ maka Ho diterima dan hipotesis alternatif (Ha) ditolak.

\section{HASIL DAN PEMBAHASAN}

\subsection{Hasil penelitian}

\section{Uji Validitas}

Uji validitas data yang digunakan untuk mengukur sah atau valid tidaknya suatu kuesioner, biasanya dilakukan uji signifikan koefisien korelasi pada taraf signifikan 0,05. Menurut Azwar dalam buku (Duwi, 2010) digunakan untuk mengukur valid tidaknya suatu kuesioner. Dalam menentukan valid atau tidaknya suatu item pengujian sering digunakan korelasiCorrected ItemTotal Correlation. Suatu item dikatakan valid apabila nilai Corrected Item-Total Correlation 
>dibandingkan 0,3. Item kuesioner yang valid dapat dijadikan acuan untuk penelitian selanjutnya.

Tabel 1 Uji Validitas

Item-Total Statistics

\begin{tabular}{|l|r|r|r|r|}
\hline & $\begin{array}{c}\text { Scale Mean if } \\
\text { Item Deleted }\end{array}$ & $\begin{array}{c}\text { Scale Variance } \\
\text { if Item Deleted }\end{array}$ & $\begin{array}{c}\text { Corrected } \\
\text { Item-Total } \\
\text { Correlation }\end{array}$ & $\begin{array}{c}\text { Cronbach's } \\
\text { Alpha if Item } \\
\text { Deleted }\end{array}$ \\
\hline Budaya & 15.7867 & .678 & .388 & .435 \\
Sosial & 15.7667 & .800 & .374 & .492 \\
Pribadi & 16.1333 & .829 & .389 & .450 \\
Psikologi & 16.1733 & .734 & .361 & .338 \\
KEPUTUSAN & 16.3000 & .714 & .502 & .367 \\
PEMBELIAN & & & \\
\hline
\end{tabular}

Dari data tabel diatas dapat dijelaskan, setelah dilakukan uji validitas dari pengolahan data dari responden didapatkan nilai Corrected Item-Total Correlation untuk masing-masing variabel budaya, variabel sosial, variabel pribadi, variabel psikologi serta variabel keputusan pembelian didapatkan nilai semuanya > dari 0,03 dan ini menjelaskan bahwa semua variabel memenuhi syarat dan valid untuk dijadikan acuan penelitian.

\section{Uji Reliabilitas}

Pengujian Reliabilitas dilakukan untuk mengetahui seberapa besar tingkat keabsahan data sehingga dapat menghasilkan data yang benar-benar sesuai dengan kenyataan dan dapat digunakan berkali-kali pada waktu yang berbeda, pengujian ini menggunakan uji Crobach alpha $(\propto)$ yaitu jika $\propto>0,60$ maka dikatakan reliabel (Ghozali, 2006), dalam arti bahwa alat ukur yang digunakan dalam penelitian ini reliabel atau dapat dipercaya.

Tabel 2. Uji Crobach alpha $(\alpha)$

Reliability Statistics

\begin{tabular}{|r|r|}
\hline $\begin{array}{c}\text { Cronbach's } \\
\text { Alpha }\end{array}$ & N of Items \\
\hline .745 & \\
\hline
\end{tabular}

Pada tabel uji realibilitas yang dilakukan dalam proses perhitungan didapat nilai Cronbach alpha sebesar 0,745 yang berarti bahwa alat ukur dalam penelitian ini reliabel atau dapat dipercaya karena memiliki nilai koefisien alpha diatas 0.60 seperti apa yang dikatakan oleh Ghozali.

\section{Uji Determinasi $\left(\mathbf{R}^{2}\right)$}

Analisis determinasi digunakan untuk mengetahui persentase sumbangan variabel independen $\left(\mathrm{X}_{1}, \mathrm{X}_{2}, \mathrm{X}_{3}, \mathrm{X}_{4}\right)$ secara serentak terhadap variabel dependen (Y) (Duwi, 2010). Jika nilai $\mathrm{R}^{2}$ sama dengan1, maka persentase sumbangan pengaruhyang diberikan variabel independen terhadap variabel dependen adalah sempurna ataubaik. Koefisien korelasi (R)adalah uji yang digunakan untuk mengetahui adanya hubungan yang kuat ataupun rendah antara kedua varibel berdasarkan nilai R menurut (Sugiyono, 2007) pedoman untuk memberikan interprestasi 
koefisien korelasi.

Tabel 3: Uji Determinasi $\left(\mathrm{R}^{2}\right)$

Model Summary ${ }^{b}$

\begin{tabular}{|c|c|c|c|c|c|c|c|c|c|c|}
\hline \multirow[t]{2}{*}{ Model } & \multirow[b]{2}{*}{$\mathrm{R}$} & \multirow[b]{2}{*}{$\begin{array}{c}\mathrm{R} \\
\text { Square }\end{array}$} & \multirow[b]{2}{*}{$\begin{array}{l}\text { Adjusted } \\
\text { R Square }\end{array}$} & \multirow{2}{*}{$\begin{array}{l}\text { Std. Error } \\
\text { of the } \\
\text { Estimate }\end{array}$} & \multicolumn{5}{|c|}{ Change Statistics } & \multirow[b]{2}{*}{$\begin{array}{l}\text { Durbin- } \\
\text { Watson }\end{array}$} \\
\hline & & & & & $\begin{array}{l}\text { R Square } \\
\text { Change }\end{array}$ & $\begin{array}{c}\mathrm{F} \\
\text { Change }\end{array}$ & df1 & df 2 & $\begin{array}{l}\text { Sig. F } \\
\text { Change }\end{array}$ & \\
\hline dimension0 & $.445^{\mathrm{a}}$ & .198 & .163 & .23879 & 198 & 5.628 & 4 & 25 & .000 & 1.944 \\
\hline
\end{tabular}

a. Predictors: (Constant), Psikologi, Budaya, Sosial, Pribadi

b. Dependent Variable: KEPUTUSAN PEMBELIAN

Dari tabel 5.6 diatas dapat diketahui nilai $\mathrm{R}$ sebesar 0,445 menunjukkan bahwa korelasi atau hubungan antara variabel dependen (keputusan pembelian) dengan variabel independen (budaya, sosial, pribadi dan psikologis) memiliki hubungan yang cukup kuat yaitu sebesar 44.5\%. Dari tabel diatas juga diketahui nilai $R$ Square sebesar 0,198. Artinya adalah bahwa sumbangan pengaruh variabel independent terhadap variabel dependen adalah sebesar 1,98\%, yang berarti sumbangan pengaruh yang diberikan variabel independen terhadap variabel dependen cukup sempurna atau cukup baik.

\section{Pengujian Hipotesis}

\section{Pengujian Hipotesis F (Secara Simultan)}

Uji $F$ pada dasarnya menunjukkan apakah semua variabel independen atau bebas mempunyai pengaruh secara bersama-sama terhadapa variabel dependen atau terikat. Untuk membuktikan secara bersama-sama, maka dilakukan uji F. Hasil uji regresi secara simultan atau uji $\mathrm{F}$ dapat dilihat pada tabel 4 dibawah ini:

Tabel 4 Hasil Uji F

\begin{tabular}{|rl|r|r|r|r|r|}
\hline \multicolumn{2}{|c|}{ Model } & $\begin{array}{c}\text { Sum of } \\
\text { Squares }\end{array}$ & $\mathrm{df}$ & Mean Square & F & Sig. \\
\hline 1 & Regression & 1.284 & 4 & .321 & 5.628 & $.000^{\mathrm{a}}$ \\
& Residual & 5.189 & 91 & .057 & & \\
& Total & 6.473 & 95 & & & \\
\hline
\end{tabular}

a. Predictors: (Constant), Psikologi, Budaya, Sosial, Pribadi

b. Dependent Variable: KEPUTUSAN PEMBELIAN

Dari Tabel 5.7.1. diatas diketahui $\mathrm{F}$ hitung sebesar 5.628 dengan signifikansi 0,000. Diketahui $\mathrm{F}_{\text {tabel }}$ dengan persamaan df $1=\mathrm{k}-1=5-1=4$ sedangkan df $2=\mathrm{n}-\mathrm{k}=30-4=26 ;=2.743$ (lihat tabel $\mathrm{F}$ pada tingkat signifikansi 5\%). Dengan demikian diketahui $\mathrm{F}_{\text {hitung }} 5,628>\mathrm{F}_{\text {tabel }} 2.743$ dan signifikansi $(0,000)<0,05$. Artinya adalah Perilaku konsumen yang terdiri dari (faktor budaya, Sosial, pribadi dan psikologis) secara serentak ataupun secara bersama-sama berpengaruh signifikan terhadap keputusan pembelian beras merah. $\left(\mathrm{H}_{0}\right.$ ditolak dan $\mathrm{H}_{1}$ diterima) yang berarti sekumpulan variabel bebas terbukti secara bermakna mempengaruhi variable terikat.

\section{Uji Parsial (Uji T)}

Pengujian parsial (individual) diadakan dengan melakukan uji t hitung, mencari besarnya $\mathrm{t}$ hitung yang akan dibandingkan dengan t tabel. Pengujian t hitung digunakan untuk mengetahui kualitas keberartian regresi antara tiap-tiap variabel bebas $(\mathrm{X})$ terdapat pengaruh atau tidak 
terhadap variabel terikat (Y), Caranya adalah dengan membandingkan antara $t_{\text {hitungdengan }} t_{\text {tabel }}$. Jika $t_{\text {hitung }}>t_{\text {tabel }}$ maka Ho ditolak dan Ha diterima, namun jika $t_{\text {hitung }} \leq t_{\text {tabel }}$ maka Ha ditolak dan Ho diterima. Berdasarkan uji regresi yang dilakukan, diperoleh hasil sebagai berikut:

Tabel 5 Hasil Uji Regresi

\section{Coefficientsa}

\begin{tabular}{|c|c|c|c|c|c|}
\hline \multirow[t]{2}{*}{ Model } & \multicolumn{2}{|c|}{$\begin{array}{c}\text { Unstandardized } \\
\text { Coefficients }\end{array}$} & \multirow{2}{*}{$\begin{array}{c}\text { Standardized } \\
\text { Coefficients } \\
\text { Beta }\end{array}$} & \multirow[b]{2}{*}{$\mathrm{t}$} & \multirow[b]{2}{*}{ Sig. } \\
\hline & B & $\begin{array}{l}\text { Std. } \\
\text { Error }\end{array}$ & & & \\
\hline $1 \quad$ (Constant) & .150 & 1.176 & & .172 & .900 \\
\hline Budaya & .365 & .143 & .445 & 2.562 & .017 \\
\hline Sosial & .370 & .216 & .434 & 1.911 & .064 \\
\hline Pribadi & .390 & .227 & .337 & 1.715 & .099 \\
\hline Psikologi & .433 & .274 & .312 & 1.542 & .164 \\
\hline
\end{tabular}

a. Dependent Variable: KEPUTUSAN PEMBELIAN

Berdasarkan hasil output uji regresi pada tabel: 5.7.2 diatas dapat dijelaskan sebagai berikut:

Dari Tabel 5.7.2 diatas dapat kita lihat masing-masing nilai thitung dan signifikansi variabel bebas, Diketahui nilai $\mathrm{t}_{\text {tabel }}$ dengan persamaan $\mathrm{n}-\mathrm{k}-1 ; \alpha / 2=30-4-1 ; 0,05 / 2=25 ; 0,025=$ 2,05954 pada signifikansi 5\%. Dengan demikian diperoleh hasil sebagai berikut:

1. Variabel Budaya $\left(X_{1}\right)$, diketahui $t$ hitung sebesar 2,562 , dengan demikian $t_{\text {hitung }}>t_{\text {tabel }}(2,562$ $>2,05954)$, Sig. $(0.017)<0,05$ yang secara parsial dan signifikan variabel budaya $\left(\mathrm{X}_{1}\right)$ mempengaruhi variabel Keputusan Pembelian (Y) atau Ho ditolak dan Ha diterima.

2. Variabel Sosial $\left(X_{2}\right) t_{\text {hitung }}$ sebesar 1,911 , dengan demikian $t_{\text {hitung }}>t_{\text {tabel }}(1,911<2,05954)$, Sig. $(0.064)>0,05$ yang secara parsial dan signifikan variabel sosial $\left(\mathrm{X}_{2}\right)$ tidak mempengaruhi variabel Keputusan Pembelian(Y) atau Ho diterima dan Ha ditolak.

3. Variabel Pribadi $\left(X_{3}\right) t_{\text {hitung }}$ sebesar 1,715 , dengan demikian $t_{\text {hitung }}>t_{\text {tabel }}(1,715<2,05954)$, Sig. (0.064) >0,05 yang secara parsialdan signifikan variabel pribadi $\left(\mathrm{X}_{3}\right)$ tidak mempengaruhi variabel Keputusan Pembelian(Y) atau Ho diterima dan Ha ditolak.

4. Variabel Psikologi $\left(\mathrm{X}_{4}\right) \mathrm{t}_{\text {hitung }}$ sebesar 1,542 , dengan demikian $t_{\text {hitung }}>t_{\text {tabel }}(1,542<2,05954)$, Sig. (0.164) $>0,05$ yang secara parsial dan signifikan variabel pribadi $\left(\mathrm{X}_{3}\right)$ tidak mempengaruhi variabel Keputusan Pembelian(Y) atau Ho diterima dan Ha ditolak.

Dari empat variabel (budaya, sosial, pribadi dan psikologi) nilai t hitung keempat varibel independen maka dapat disimpulkan bahwa variabel budaya yang berpengaruh dalam pengambilan keputusan pembelian dengan nilai t hitung tersebesar diantara variabel lain yaitu sebesar 2.562 .

\subsection{Pembahasan}

Berdasarkan hasil analisis dengan melakukan menggunakan analisis berupa uji validitas, uji reliabilitas, regresi linear berganda, koefisien determinasi (R2), uji F dan uji t. Berdasarkan hasil analisis diperoleh persamaan regresi $\mathrm{Y}=0.150+0.365 \mathrm{X} 1+0.370 \mathrm{X} 2+0.390 \mathrm{X} 3+$ $0.433 \mathrm{X} 4+\mathrm{e}$. Dari persamaan regresi dapat dikatakan bahwa keputusan pembelian beras merah di pasar Tembok Surabaya dipengaruhi oleh faktor budaya (X1) sebesar 0,365, sosial (X2) sebesar 0.370, pribadi (X3) sebesar 0.390 serta psikologis (X4) sebesar 0.433. Dari hasil uji hipotesis $t$ 
diperoleh nilai t hitung variabel budaya sebesar 2,562, variabel sosial sebesar 1,911, variabel pribadi sebesar 1,715, variabel psikologis sebesar 1,542. Dari data diatas hanya variabel budaya yang berpengaruh dengan dengan nilai 2,562 sehingga nilai thitung > dibandingkan dengan nilai ttabel 2,05954, hal ini menunjukkan bahwa hanya variabel budaya yang berpengaruh secara signifikan terhadap variabel dependen. Berdasarkan uji simultan F nilai Fhitung sebesar 5,628 > Ftabel 2,7822 dan signifikansi $0,000<0,05$. Hasil uji korelasi $\mathrm{R}$ diketahui nilai $\mathrm{R}$ 0,455 maka korelasi $\mathrm{R}$ antara variabel $\mathrm{X}$ dan $\mathrm{Y}$ memiliki hubungan yang kurang kuat. Sedangkan didapat nilai R2 sebesar 19,8\% artinya 19,8\% dari keputusan pembelian dipengaruhi oleh budaya, sosial, pribadi dan psikologis. Sedangkan keputusan terbesar konsumen dalam pembelian beras merah di pasar Tembok Surabaya dipengaruhi oleh variabel lain sebesar sisanya 80,2\% dipengaruhi oleh variabel lain diluar penelitian ini.

\section{KESIMPULAN}

\section{Kesimpulan}

1) Dari hasil uji validitas, diperoleh nilai nilai Corrected Item-Total Correlation untuk masingmasing variabel budaya, variabel sosial, variabel pribadi, variabel psikologi serta variabel keputusan pembelian didapatkan nilai semuanya > dari 0,03 dan ini menjelaskan bahwa semua variabel memenuhi syarat dan valid untuk dijadikan acuan penelitian

2) Dari hasil uji reabilitas, yang dilakukan dalam proses perhitungan didapat nilai Cronbach alpha sebesar 0,745 yang berarti bahwa alat ukur dalam penelitian ini reliabel atau dapat dipercaya karena memiliki nilai koefisien alpha diatas 0.60 .

3) Berdasarkan hasil analisis diperoleh persamaan regresi $\mathrm{Y}=0.150+0.365 \mathrm{X} 1+0.370 \mathrm{X} 2+$ $0.390 \mathrm{X} 3+0.433 \mathrm{X} 4+\mathrm{e}$ konstanta sebesar 0,150 . Yang dapat diartikan apabila nilai bebas sebesar 0, maka nilai Y sebesar 0,150 dengan koefisien variabel budaya (X1) sebesar 0,365, sosial (X2) sebesar 0.370, pribadi (X3) sebesar 0.390 serta psikologis (X4) sebesar 0.433 yang berarti bernilai positif. Yang artinya apabila semakin besar nilai dari variabel-variabel tersebut maka keputusan pembelian akan semakin meningkat.

4) Dari hasil uji hipotesis t diperoleh nilai thitung variabel budaya sebesar 2,562, variabel sosial sebesar 1,911, variabel pribadi sebesar 1,715, variabel psikologi ssebesar 1,542. Dari data diatas hanya variabel budaya yang berpengaruh dengan dengan nilai 2,562 sehingga nilai thitung > dibandingkan dengan nilai ttabel 2,05954, hal ini menunjukkan bahwa hanya variabel budaya yang berpengaruh secara signifikan terhadap variabel dependen.

5) Berdasarkan uji simultan F nilai Fhitung sebesar 5,628 > Ftabel 2,7822 dan signifikansi 0,000 $<0,05$. Hasil uji korelasi $\mathrm{R}$ diketahui nilai $\mathrm{R} 0,455$ maka korelasi $\mathrm{R}$ antara variabel $\mathrm{X}$ dan $\mathrm{Y}$ memiliki hubungan yang kurang kuat. Sehingga secara signifikan hanya variabel budaya yang mempunyai pengaruh terhadap keputusan beras merah di pasr Tembok Surabaya, sedangkan variabel sosial, pribadi dan psikologis berpengaruh sangat kecil.

6) Sedangkan dari hasil nilai R2 sebesar 19,8\% artinya 19,8\% dari keputusan pembelian dipengaruhi oleh budaya, sosial, pribadi dan psikologis. Sedangkan keputusan terbesar konsumen dalam pembelian beras merah di pasar Tembok Surabaya dipengaruhi oleh variabel lain sebesar sisanya 80,2\% dipengaruhi oleh variabel lain diluar penelitian ini. Dari hasil diatas dapat disimpulkan bahwa keempat variabel bebas (budaya, sosial, pribadi dan psikologi) secara bersama-sama tidak memberikan pengaruh terhadap variabel terikat 


\section{Saran}

1) Beras merah masih menjadi barang konsumsi yang mungkin bagi sebagian konsumen atau calon konsumen yang bernilai ekonomi atau masih menjadi barang skunder sehingga untuk meningkatkan minat calon konsumen, perlu adanya pilihan berkaitan dengan macam harga yang bisa disesuaikan dengan kemampuan calon konsumen.

2) Perlu dilakukan oleh para produsen beras merah untuk secara kontinue mengenalkan produkproduk beras merah baik dengan promosi langsung pada pasar-pasar beras maupun pada pasar-pasar tradisional berkaitan dengan manfaat dan kelebihan beras merah dengan beras biasa.

3) Dari hasil perhitungan yang di dapat dalam penelitian ini yang paling mempunyai pengaruh dalam penelitian ini adalah variabel budaya yang menjadi pertimbangan konsumen dalam mengambil keputusan pembelian beras merah di pasar Tembok Surabaya, sehingga guna meningkatkan minat masyarakat dalam mengkonsumis beras merah pihak produsen mempunyai kewajiban untuk lebih mengenalkan manfaat beras merah bagi kesehatan dan menyediakan pilihan khususnya pilihan harga.

4) Guna mempertahankan jumlah konsumen beras merah di pasar Tembok Surabaya dan terus meningkat, perlu pihak produsen dan pihak penjual untuk bekerja sama dalam melakukan promosi atau menyediakan outlet tersendiri untuk produk beras merah, menyediakan sales promotion pada waktu-waktu tertentu atau memberikan diskon dan sejenisnya pada pembelian beras merah di pasar Tembok Surabaya pada saat-saat tertentu.

\section{DAFTAR PUSTAKA}

Andriana, E. (2006). Beras merah kaya vitamin dan mineral.

Armstrong, G., Adam, S., Denize, S., \& Kotler, P. (2014). Principles of marketing. Pearson Australia.

Azwar, S. (2012). Reliabilitas dan validitas. Yogyakarta: Pustaka Pelajar.

Duwi, P. (2010). Teknik mudah dan cepat melakukan analisis data penelitian dengan SPSS. Yogyakarta: Gava Media. Edisi, 4.

Fitriani, V. (2006). Getah Sejuta Manfaat. PT. Trubus Swadaya. Edisi April 2006. Jakarta.

Ghozali, I. (2006). Aplikasi analisis multivariate dengan program SPSS. Badan Penerbit Universitas Diponegoro.

Hartono, S. (2004). untuk Penelitian. Yogyakarta: Pustaka Pelajar Offset.

Imam, G. (2005). Aplikasi analisis multivariate dengan program SPSS. Semarang: Badan Penerbit Universitas Diponegoro.

Istijanto, M. M. (2013). Riset sumber daya manusia. Gramedia Pustaka Utama.

Kotler, P., \& Amstrong, G. (2004). Dasar-dasar pemasaran edisi kesembilan Jilid 1. Jakarta: PT Indeks. 
Sangadji, E. M. (2017). Perilaku Konsumen; Pendekatan praktis disertai himpunan jurnal penelitian.

Santika, A., ; Rozakurniati. (2010). Teknik Evaluasi Mutu Beras Hitam dan Beras Merah pada Beberapa Galur Padi Gogo. Buletin Teknik Pertanian Vol. 15 No. 1.

Setiadi, N. J. (2010). Perilaku konsumen: perspektif kontemporer pada motif, tujuan, dan keinginan konsumen.

Setiadi, N. J. (2015). Perilaku Konsumen. Jakarta: Kencana.

Sugiyono, M. (2007). Kualitataif dan r\&d, Bandung: Alfabeta, 2010. Sugiyono, Metode Penelitian Kuantitatif Kualitatif Dan R\&D Bandung: Alfabeta.

Supranto, J., \& Limakrisna, N. (2007). Perilaku konsumen dan strategi pemasaran untuk memenangkan persaingan bisnis. Jakarta: Mitra Wacana Media.

Suryani, T. (2013). Perilaku Konsumen di Era Internet: Implikasinya pada Strategi Pemasaran. Graha Ilmu.

Sutisna, S. (2013). Perilaku konsumen dan komunikasi pemasaran. Jakarta: PT. Remaja Rosdakarya.

Utami, C. W. (2008). Manajemen barang dagangan dalam bisnis ritel. Edisi pertamaAgustus 2008-ISBN: 978-979-3323-93-0-Bayumedia Publishing. 